\title{
TEACHING PRAGMATICS IN THE EFL CLASSROOM: CHALLENGES, LACUNAS, AND SUGGESTIONS
}

\author{
Maryam Sharif \\ Department of English Language, Shiraz Branch, Islamic Azad University, Shiraz, Iran \\ maryamsharif900@yahoo.com \\ Lotfollah Yarmohammadi \\ Department of English Language, Shiraz Branch, Islamic Azad University, Shiraz, Iran \\ 1.yarmohammadi@yahoo.com \\ Firooz Sadighi \\ Department of English Language, Shiraz Branch, Islamic Azad University, Shiraz, Iran \\ firoozsadighi@yahoo.com \\ Mohammad Sadegh Bagheri \\ Department of English Language, Shiraz Branch, Islamic Azad University, Shiraz, Iran \\ bagheries@gmail.com
}

\begin{abstract}
Within the last few decades, interlanguage pragmatics research has risen to its due prominence under the influence of Hymes and the subsequent models of Communicative Competence (CC). Among different components of CC, a large number of L2 studies have attended to the construct pragmatic competence, which deals with both pragmalinguistic knowledge and sociopragmatic knowledge. As such, interlanguage pragmatics research is interested in the pragmatic competence and pragmatic performance of L2 learners; however, teaching pragmatics to Non-native Speakers (NNSs), especially EFL learners, is a thorny issue. As a result, pragmatic competence has been noticeably absent from ELT curricula, despite the fact that it has an assured place in different models of CC. The reasons for this neglect lie behind the obstacles to teaching and learning pragmatics in the ESL/EFL classroom settings. Thus, drawing on the published literature, this very paper primarily aims at discussing challenges and lacunas in teaching and learning pragmatics within the confines of EFL classrooms. Subsequent to this, the paper enlists suggestions to overcome these obstacles. To this end, the paper focuses on four broad areas: the EFL context, ELT materials and resources available to L2 learners in the EFL context, teacher education, and assessment of pragmatic knowledge.
\end{abstract}

Keywords: pragmatics, EFL classroom settings, materials development, teacher education, assessment

\section{Introduction}

Over the last five decades, we have witnessed great changes in our perception of how languages are learnt and thus should be taught (Usó-Juan \& Martínez-Flor, 2008). Among different approaches, 'communicative language teaching' has become the most widely accepted method for language instruction, the principal objective of which is to enhance language learners' CC (Usó-Juan \& Martínez-Flor, 2008).

The notion of $\mathrm{CC}$ has become an interesting topic for analysis in second language acquisition research. Consequently, different scholars in the field have attempted to describe the construct $\mathrm{CC}$ by identifying its components. Among different components of CC, a large number of L2 studies have attended to pragmatic competence.

Even though our conceptualisation of pragmatic competence has been immensely influenced by different models of CC (Taguchi, 2011), Thomas (1983) conceives of pragmatic competence as involving both pragmalinguistic and sociopragmatic knowledge. The former refers to "the linguistic resources available to perform language functions" (Taguchi, 2011, p. 289), and the latter deals with "the language user's assessment of the context in which such resources are implemented" (ibid). The two areas of pragmatic competence seem to be difficult for EFL/ESL learners to acquire (O'Keeffe, Clancy, \& Adolphs, 2011) since to be pragmatically competent, L2 learners must know how to map their sociopragmatic knowledge onto pragmalinguistic forms under the contextual constraints of the situation (Roever, 2004, as cited in Mirzaei, Roohani, \& Esmaeili, 2012).

Accordingly, tackling the nuances of pragmatics is a challenge to NNSs (O'Keeffe et al., 2011), and the complexity is enhanced in the EFL context. Undoubtedly, ESL and EFL learners differ in the amount of pragmatic input available to them (Webb, 2013). Unlike the ESL context wherein L2 learners are surrounded by the bath of English in their daily life (LoCastro, 2012), EFL learners have less exposure to authentic language use and thus fewer opportunities to practice English outside the walls of the EFL classroom. Hence, they have to rely on instruction, textbooks, and TV/radio programmes (Webb, 2013). 
In addition, pragmatic knowledge does not seem to develop as naturally as grammatical competence (O'Keeffe et al., 2011). In other words, a high level of grammatical competence does not guarantee high pragmatic ability (O'Keeffe et al., 2011). The mismatch between L2 learners' grammatical and pragmatic competencies has often been reported in the literature (see Badovi-Harlig \& Dörnyei, 1998, for instance).

The drawbacks imposed by limitations of the EFL context have sparked a large number of pragmatic studies in the EFL sphere. Therefore, this article aims at reviewing a number of these studies focusing its attention on challenges that EFL learners and teachers face in the acquisition and instruction of L2 pragmatic norms within the EFL classroom environment. Subsequently, suggestions are made to overcome these challenges. In discussing the challenges and suggesting possible solutions, this article has limited its scope to four broad areas: the EFL context, ELT materials and resources available in the EFL context, teacher education, and assessment of pragmatic knowledge.

\section{Challenges in Teaching and Learning Pragmatics within the EFL Context The EFL Classroom Setting}

For L2 learners, development of pragmatic competence generally has to take place in instructional settings (LoCastro, 2012). However, instructional environments are limited in many ways (LoCastro, 2012). For instance,

classroom environments world-wide are commonly teacher-centred, structured to complete the syllabus with little time during lessons to facilitate practice of language where learners are involved in comprehension and production of pragmatic meaning. [And] the opportunities to use the target language in situations that approach real world conversation are limited. (LoCastro, 2012, p.130)

The complexity is even added when it comes to pragmatic classroom practices in an EFL environment. Native Speakers (NSs) learn the social rules of speaking through socialising at home, at school, and in society (LoCastro, 2012). However, for EFL learners, learning rules of appropriateness are extremely difficult as there are almost no opportunities for interaction with NSs (LoCastro, 2012). On the other hand, EFL learners have little, if any, exposure to English outside the classroom; hence, they might be at a disadvantage to ESL learners.

The EFL classroom setting may impose limitations on the acquisition and instruction of pragmatics in several ways. First, within the EFL context, micro-level grammatical accuracy takes priority over macrolevel pragmatic appropriateness due to the dominance of structural syllabus (Bardovi-Harlig \& Dörnyei, 1998). Second, within the EFL classroom setting, language is treated as an object rather than a means of communication, and opportunities for socialisation are limited (Cook, 2001). Third, the classroom environment usually suffices to a few speech acts and cannot replicate the real-world language use; as such, it cannot well prepare language learners for conversing easily in the target language community (Webb, 2013). Finally, within the EFL context, teachers serve as a primary source of input for EFL learners. Nevertheless, non-native teacher talk can be characterised by a number of features: first, it is replete with direct strategies as teachers are often in a state of power (Nikula, 2002), and this "asymmetrical power relationship" between the teacher and the students might influence the pragmatic aspects of teachers' talk (Nikula, 2002, p. 456); second, as EFL learners and teachers rely heavily on their textbooks, the English used in the classroom is often in the form of "materials-dependent talk" (Nikula, 2002, p. 454), the fact that makes non-native teacher talk seem verbatim, unnatural, and at odds with face-to-face conversations; finally, within the EFL context, teacher-learner relationship is hierarchical (Webb, 2013); therefore, classroom language seems to be more polite than real-world language use (Kasper \& Rose, 2002, cited in Webb, 2013).

\section{ELT Textbooks}

Within the EFL context, instructional materials, in particular textbooks, can serve as an important source for teaching L2 pragmatic norms since learners oftentimes interact with their textbooks, and their teachers use textbooks as a guide (Morady Moghaddam, 2012). However, we cannot always count on textbooks as reliable sources of pragmatic input for L2 learners (Bardovi-Harlig, 2001), for they are primarily based on the author's intuition rather than empirical research and thus are often inadequate, simplistic, and at times incorrect for presenting L2 pragmatic norms (Olshtain \& Cohen, 1991; O'Keeffe et al., 2011; LoCastro, 2012). For instance, textbooks that deal with apology speech act have focused merely on the expressions of apology with no reference to its semantic formulas or realisation strategies (Olshtain \& Cohen, 1991); in other words, there is no mention of when to say what (Olshtain \& Cohen, 1991) or how to say it effectively (Cohen, 2012). 
In addition, textbooks substantially lack authenticity as corpus studies have shown inconsistencies between the English found in textbooks and the English which appears in spoken/written corpora (O'Keeffe et al., 2011). Therefore, textbooks cannot prepare EFL learners for unrehearsed real-life performance.

Last but not least, the activities and tasks designed for practice purposes are limited in the coverage of communication scenarios they present, and they provide superficial practice for realisations of different speech acts (Biesenbach-Lucas, 2003).

\section{Teachers and Teacher Education}

Teachers still hesitate to teach pragmatics in EFL classrooms (Jianda, 2006) for several reasons:

First, many EFL teachers may not have adequate knowledge of what pragmatics is or how to teach it; hence, they might feel at a loss as they are not NSs of English and might lack metapragmatic awareness of the L2 pragmatic norms (LoCastro, 2012).

Second, most EFL teachers have an overloaded curriculum to cover (Usó-Juan \& Martinez-Flor, 2008) and are often pressed for time as they have to prepare students for tests (Cai \& Wang, 2013), for success in the exam is given more credit in the EFL classroom than successful communication with NSs (BardoviHarlig \& Dörnyei, 1998).

Third, EFL teachers seldom have access to pragmatics research findings (Webb, 2013). Besides, there seems to be a gap in what research has found and how pragmatics is taught (Cohen, 2012). Hence, teachers have to rely on their intuition in teaching pragmatics (Webb, 2013).

Fourth, teachers may serve as a major source of input for L2 learners. However, they have their own identities (LoCastro, 2012), and their teaching activities or the input they provide to L2 learners may not be impartial.

Above all, EFL teachers' reluctance to teach pragmatics lies in the fact that pragmatic issues seldom, if at all, are brought to EFL teachers' attention in teacher education and professional development programmes. Pragmatics has often been a Cinderella in teacher training programmes, and "to date, the silence on teacher knowledge in this area has been deafening" (Yates \& Wigglesworth, 2005, p. 263). Furthermore, in case pragmatics has received some attention at all, the coverage has been at the level of theory and has not addressed how to teach pragmatics in the L2 classroom (Cohen, 2012). This neglect most probably results from lack of emphasis on different aspects of pragmatics in language teaching methodology courses (EslamiRasekh, 2005).

\section{Corrective Feedback and Assessment of Pragmatic Knowledge}

According to LoCastro (2012), adult L2 learners rarely receive any corrective feedback on their pragmatic glitches. This is particularly true for EFL learners, whose teachers often do not know when and how to provide corrective feedback. Even though a large body of research has looked into the effects of corrective feedback on different aspects of language, there is a dearth of research on the instructional values of corrective feedback at the pragmatic level. This calls for further investigation to examine whether and how corrective feedback is provided in language classrooms and how L2 learners react to pragmatic error correction.

Furthermore, despite the rise in interlanguage pragmatics studies, valid methods of assessing pragmatic knowledge are obviously absent (Jianda, 2006). "Even the world's most communicative tests lack a systematic pragmatic component" (Bardovi-Harlig \& Dörnyei, 1998, p. 254). We do not know yet how to assess the performance of speech acts in language classrooms despite the large body of work on speech acts (O'Keeffe et al., 2011). Except for Farhady's (1980) functional test (cited in Tajeddin, 2014), no other test of pragmatic ability has been publicised to date. Therefore, teachers generally avoid classroom assessment of pragmatic knowledge (Cohen, 2014). This is especially true for non-native teachers who believe they are unable to judge about appropriate pragmatic behaviour in the target language. Hence, tests of pragmatic knowledge have not been part of classroom assessment (Cohen, 2014).

\section{Suggestions to Facilitate Teaching and Learning of Pragmatics in the EFL Context}

In this section, a number of suggestions to enhance EFL learners' pragmatic knowledge are presented:

\section{ELT Textbooks and Resources}

As it was mentioned before, in the past, most commercially available textbooks used for L2 instruction lacked any empirical basis and were prepared based on the writers' intuition (Olshtain \& Cohen, 1991). Therefore, materials developers are now advised to draw on empirical research findings in the preparation of ELT textbooks and materials. One such textbook series is the ESL Series published by Bodman and Lonzano (1981, 1984, as cited in Olshtain \& Cohen, 1990). The two books in this series provide a thorough coverage of apology speech act including reference to its semantic formulas and its modification (Olshtain \& Cohen, 1990). 
Besides, the books must be supplemented with carefully sequenced communicative activities moving from controlled to less controlled activities (Nunan, 1999, cited in Biesenbach-Lucas, 2003; Brown, 2000, cited in Biesenbach-Lucas, 2003) as available activities designed for practice purposes do not provide learners with adequate practice to automatise realisation of speech acts (Biesenbach-Lucas, 2003).

Additionally, as pragmatics teaching materials must entail at least three key elements (i.e., social context, language use, and interaction) (Taguchi, 2011), Taguchi (2011) has proposed three types of tasks to be included in pragmatics materials: conscious-raising tasks, receptive-skills tasks, and productive-skills tasks.

Apart from traditional pragmatics teaching materials, technology has brought new opportunities for pragmatics instruction and practice. For instance, videotapes of naturalistic interactions can serve as an effective medium for explicit instruction of pragmatics (see Dufon, 2004 for details). More recently, thanks to the latest advances in the use of computers, computer-assisted language learning has provided us more opportunities for teaching and learning pragmatics (Taguchi, 2011). Social networking and virtual social platforms provide other technological facilities for practising pragmatics (Taguchi, 2011). Similarly, the Internet and the World Wide Web have come to our aid to facilitate pragmatics teaching and learning. As such, a few websites have been dedicated to L2 pragmatics (see www.carla.umn.edu or www.indiana.edu/ discprag/).

\section{Teacher Education}

Needless to say, teacher-training in pragmatics is critical (Taguchi, 2011), and teacher educators must convince EFL teachers that pragmatics must become an integral part of L2 instruction (Bardovi-Harlig \& Dörnyei, 1998); besides, teacher educators must provide practical insights into how to teach pragmatics in the language classroom (Cohen, 2012) since "the focus on empirically validated pragmatics in teacher development programmes would ideally result in greater emphasis on it in the L2 classroom" (Cohen, 2012, p. 34). As such, Bardovi-Harlig and Mahan-Taylor (2003, as cited in O'Keeffe et al., 2011, p. 141), propose three pedagogical practices for teaching pragmatics to L2 learners, which are as follows: "1) the use of authentic language samples; 2) input first followed by interpretation and/or production; 3) and the introduction of the teaching of pragmatics at early levels".

\section{Corrective Feedback and Assessment of Pragmatic Knowledge}

Undoubtedly, providing corrective feedback in pragmatics could help L2 learners move towards nativelike pragmatic norms. However, EFL teachers must be cautious about how to make corrections at the pragmatic level since correcting sociopragmatic failure is a more delicate issue than correcting pragmalinguistic failure (Thomas, 1983). According to Thomas (1983),

sociopragmatic decisions are social before they are linguistic, and while foreign learners are fairly amenable to corrections which they regard as linguistic, they are justifiably sensitive about having their social (or even political, religious, or moral) judgement called into question. (p. 104)

Moreover, as it was mentioned in Section 2.4., even if teachers teach pragmatics in EFL classrooms, they do not adequately assess it (Cohen, 2014). Since one cannot deny the significance of pragmatics in developing communicative ability, Cohen (2014) recommends teachers to include assessment of pragmatic knowledge in short and long tests and proposes the following six strategies for assessing pragmatics:

1. Keep the speech act situations realistic (for the learner group) and engaging.

2. Check for key aspects of performance.

3. Have a discussion with the students after they have performed speech acts.

4. Have the students compare their performance with that of a native.

5. Have the students provide a rationale for why they responded as they did in the given social situation.

6. Be strategic about when to assess what. (pp. 16-18)

Likewise, in an attempt to provide a general framework for the assessment of interlanguage pragmatics, Tajeddin (2014) has proposed a theoretical and an operational definition for pragmatic competence, which can guide EFL teachers in the assessment of pragmatic knowledge (see Tajeddin, 2014).

\section{Conclusion}

This article was an attempt to address factors that get in the way of teaching and learning pragmatics within the EFL classroom setting and to make suggestions to overcome those barriers. To this end, the article reviewed the existing literature in four areas: EFL classroom settings, teaching materials and resources, teacher education, and assessment. 
In addition to the aforementioned factors that restrict teaching and learning of pragmatics in the EFL milieu, there are other factors related to individual learners, which may negatively affect the instruction and acquisition of L2 pragmatic norms. Discussion of these factors is beyond the scope of this article and awaits further studies.

To conclude, it must be stated that "equipping oneself to be knowledgeable about pragmatic competence is as important as developing one's IT and technology skills. Both are indispensable tools for the world of today, irrespective of one's regional or geographical location" (LoCastro, 2012, p. 308). Consequently, L2 learners need to familiarise themselves with different aspects of pragmatic competence, since gaining pragmatic knowledge serves to benefit learners in different ways.

Likewise, successful instruction of pragmatic competence requires collaboration of teachers, teacher educators, materials developers, and test designers. In particular, it is teachers who are on the frontlines of pragmatic development agenda. Therefore, they must incorporate pragmatics into their teaching practices along with vocabulary and grammar.

\section{References:}

Bardovi-Harlig, K. (2001). Evaluating the empirical evidence: Grounds for instruction in pragmatics. In K. Rose, \& G. Kasper (Eds.), Pragmatics in language teaching (pp. 13-32). Cambridge: Cambridge University Press. https://doi.org/10.1017/cbo9781139524797.005

Bardovi-Harlig, K., \& Dörnyei, Z. (1998). Do language learners recognise pragmatic violations? Pragmatic vs. grammatical awareness in instructed L2 learning. TESOL Quarterly, 32(2), 233-262. https://doi.org/10.2307/3587583

Biesenbach-Lucas, S. (2003). Speakers and task type: Increasing awareness of factors in speech act production. In K. Bardovi-Harlig, \& R. Mahan-Taylor (Eds.), Teaching pragmatics. Washington DC: Office of English Language Programmes, US Department of State.

Cai, L., \& Wang, Y. (2013). Interlanguage pragmatics in SLA. Theory and Practice in Language Studies, 3(1), $142-147$. https://doi.org/10.4304/tpls.3.1.142-147

Cohen, A. D. (2012). Teaching pragmatics in the second language classroom. The European Journal of Applied Linguistics and TEFL, 1(1), 35-49. Retrieved April 29, 2015 from https://a/umn.edu/andrewdcohen/publications/pragmatics

Cohen, A. D. (2014). Towards increased classroom assessment of pragmatic ability. Iranian Journal of Language Testing, 4(1), 5-25. Retrieved May 7, 2014 from http://ijlt.ir/ journal/images/PDF/420-2014-4-1.pdf

Cook, H. M. (2001). Why can't learners of JFL distinguish polite from impolite speech styles. In K. Rose, \& G. Kasper (Eds.), Pragmatics in language teaching (pp. 80-102). Cambridge: Cambridge University Press.

Dufon, M.A. (2004). Producing a video for teaching pragmatics in the second or foreign language classroom. Prospect, 19(1), 65-83. Retrieved November 1, 2015 from http:// www.ameprc.mq.edu.au/resources/prospect/V19_N1_2004

Eslami-Rasekh, Z. (2005). Raising the pragmatic awareness of language learners. ELT Journal, 59(3), 199-208. https://doi.org/10.1093/elt/cci039

Jianda, L. (2006). Assessing EFL learners' interlanguage pragmatic knowledge: Implications for testers and teachers. Reflections on English Language Teaching, 5(1), 1-22. Retrieved May 7, 2014 from http://www.nus.edu.sg/ celc/publications/LiuVol5.pdf

LoCastro, V. (2012). Pragmatics for language educators: A sociolinguistic perspective. New York: Routledge.

Mirzaei, A., Roohani, A., \& Esmaeili, M. (2012). Exploring pragmalinguistic and sociopragmatic variability in speech act production of L2 learners and native speakers. The Journal of Teaching Language Skills, 4(3), 79-102. Retrieved July 8, 2014 from http://jtls.shirazu.ac.ir/article_622_c00b67e043234250164d19dfda24a3f4.pdf

Morady Moghaddam, M. (2012). Discourse structures of condolence speech act. Journal of English Language Teaching and Learning, 4(10), 105-125. Retrieved May 20, 2014 from http://elt.tabrizu.ac.ir/article_609.html

Nikula, T. (2002). Teacher talk reflecting pragmatic awareness: A look at EFL and content-based classroom settings. Pragmatics, 12(4), 447-467. https://doi.org/10.1075/prag.12.4.03nik

O'Keeffe, A., Clancy, B., \& Adolphs, S. (2011). Introducing pragmatics in use. London: Routledge.

Olshtain, E., \& Cohen, A. (1990). The learning of complex speech act behaviour. TESL Canada Journal, 7(2), 45-65. https://doi.org/10.18806/tesl.v7i2.568

Olshtain, E., \& Cohen, A. (1991). Teaching speech act behaviour to nonnative speakers. In M. Celce-Murcia (Ed.), Teaching English as a second or foreign language (pp. 154-165). Boston: Heinle \& Heinle Publishers.

Taguchi, N. (2011). Teaching pragmatics: Trends and issues. Annual Review of Applied Linguistics, 31, 289-310. https://doi.org/10.1017/s0267190511000018

Tajeddin, Z. (2014). Interlanguage pragmatics and language teaching. Tehran: Jungle Publications.

Thomas, J. (1983). Cross-cultural pragmatic failure. Applied Linguistics, 4(2), 91-112. https://doi.org/10.1093/applin/4.2.91

Usó-Juan, E., \& Martínez-Flor, A. (2008). Teaching intercultural communicative competence through the four skills. Revista Alicantina de Estudios Ingleses, 21, 157-170. https://doi.org/10.14198/raei.2008.21.09

Webb, C. (2013). Teaching pragmatics to international students in private language schools in the UK. Contemporary English Teaching and Learning in Non-English-Speaking Countries, 2(2), 27-41. Retrieved April 29, 2015 from http://www.Cetljournal.co.uk/ article/view/12171/8265

Yates, L., \& Wigglesworth, G. (2005). Researching the effectiveness of professional development in pragmatics. In N. Bartels (Ed.), Applied linguistics and language teacher education (pp. 261-279). New York: Springer. 